\title{
PATHWAYS OF DENDRITIC CELL DIFFERENTIATION AND DEVELOPMENT
}

\author{
JUSTIN A. ROAKE \\ Oxford
}

\section{THE DENDRITIC CELL LINEAGE}

Dendritic cells (DC) are specialised antigen presenting cells that form a critical component of the immune defence system in which they are central to the induction of many primary immune responses ${ }^{1}$ including the response to allografted tissues. ${ }^{2}$ All tissues of the body, with the possible exception of the brain, ${ }^{3}$ contain resident leucocytes (probably less than $1-3 \%$ of the total cell complement of most tissues) that belong to the DC lineage. ${ }^{4-7}$ In solid organs such as the heart and kidney they are distributed within the interstitial spaces but in many tissues they form a network within epithelial, mesothelial or endothelial surfaces. The Langerhans cell (LC) network of the epidermis is the bestcharacterised example but a similar network is present in the airways, gastrointestinal tract, peritoneum and beneath the endothelium of major blood vessels (J. A Roake, C. P. Larsen and J. M. Austyn, unpublished observations). These cells, which are known as non-lymphoid DC to distinguish them from the DC found within the lymphoid organs, are specialised for antigen capture and translocation of antigens acquired in the periphery to the draining lymph nodes or spleen. Within lymphoid tissues DC are located predominantly in the $\mathrm{T}$ cell-dependent areas (paracortex of lymph nodes; central white pulp of the spleen) where they are known as interdigitat ing cells (IDC). The primary function of lymphoid $\mathrm{DC}$ is activation of antigen-specific T cells, ${ }^{8}$ except that in the thymus, where DC are located predominantly in the medulla, they appear to be involved in deletion of autoreactive $\mathrm{T}$ cell clones (so-called negative selection). ${ }^{9}$

In this review the features of the phenotypically and functionally diverse DC lineage will be discussed, but further consideration of thymic DC will be omitted, and the concept of progressive differ-

Correspondence to: Justin A. Roake, DPhil, FRACS, Nuffield Department of Surgery, University of Oxford, John Radcliffe Hospital, Headington, Oxford OX3 9DU, UK. entiation from bone marrow progenitors to lymphoid DC will be developed.

\section{LYMPHOID DENDRITIC CELLS}

Dendritic cells cannot be defined by a single characteristic because the lineage is diverse and, to date, no lineage-specific markers have been identified. DC are therefore defined by the sum of multiple characteristics and the absence of others. It is perhaps best to define DCs by reference to the characteristics of lymphoid DC since these were the first to be characterised ${ }^{8,10-12}$ and they appear to represent fully differentiated cells. In fact, there is no evidence that lymphoid DC proliferate to any appreciable extent, and they do not appear to recirculate via the blood or lymph. Thus, they can be considered to be 'end cells', the final result of the development process.

The characteristics of lymphoid DC have been reviewed in detail elsewhere ${ }^{1}$ and only a brief account will be given here. Lymphoid DC are bone marrow-derived leucocytes that express the leucocyte common antigen (CD45). They also express high levels of MHC class I and II and other cell surface antigens (for example CD4 (human subset), CD8 (human subset), CD11b, CD25, CD58) including molecules such as ICAM-1 (CD54), B7-1 (CD80), B7-2 (CD86), and CD40 which may have important 'co-stimulatory' functions. In the mouse certain subsets express DC-restricted markers (N418 (CD11c), NLDC145, M342, 33D1). They lack lineage-specific markers for $\mathrm{T}$ cells (CD3, $\mathrm{T}$ cell receptor), B cells (CD19, surface immunoglobulin), monocytes (CD14) and NK cells (CD56, CD57). When isolated and observed in culture they have an irregular 'dendritic' shape and exhibit motility, constantly changing their shape by extending out cytoplasmic veils and processes apparently continuously sampling the environment around them. They have limited phagocytic or endocytic capacity and consistent with this they express few or no $\mathrm{Fc}$ 
receptors (Fc $\gamma \mathrm{R}$ : CD16, CD32, CD64) or complement receptors (C3R: CD11b, CD21, CD35) and they process antigens poorly. Isolated DC are capable of 'homing' to the T-dependent areas of the lymphoid tissues when returned to the body by injection. ${ }^{13,14}$ They cluster spontaneously with $\mathrm{T}$ cells in vitro and possess potent capacity to activate naïve $\mathrm{T}$ cells. This is often referred to as immunostimulatory activity.

\section{DENDRITIC CELLS IN NON-LYMPHOID TISSUES}

Epidermal LC (see Romani and Schuler ${ }^{4}$ for review) form a virtually continuous network over almost the entire external surface of the body including the conjunctiva and peripheral cornea, but excluding the central cornea which is normally virtually devoid of DC. They, and other surface-associated DC, are ideally situated as 'sentinels' strategically placed to encounter invading foreign antigens. ${ }^{15}$ Functionally, they appear to be specialised for antigen capture and processing. Freshly isolated LC are efficient at uptake and processing of soluble protein antigens in vitro. ${ }^{16}$ In addition they express surface molecules such as Fc receptors (FcyRII; CD32) and complement receptors (C3R; CD11b) ${ }^{17}$ which may assist in the uptake of opsonised antigens and it is known that particulate antigens can be internalised by $\mathrm{LC}^{18}$ and interstitial $\mathrm{DC},{ }^{6}$ but this phagocytic capacity is much less avid and more selective than that of 'professional' phagocytes such as macrophages. Following uptake, exogenous protein antigens are processed within the endosomes/lysosomes and expressed at the cell surface as peptides in association with MHC class II. At this stage of development LC, ${ }^{19}$ and other non-lymphoid $\mathrm{DC},{ }^{6}$ are relatively poor stimulators of $\mathrm{T}$ cell proliferation in vitro and consistent with this they express low levels of B7 co-stimulatory molecules. ${ }^{20,21}$

In tissue culture non-lymphoid DC undergo dramatic phenotypic and functional changes which together are considered to represent a 'maturation' process during which they come to resemble lymphoid DC. ${ }^{6,17,19}$ In the case of LC, the capacity for antigen uptake by phagocytosis is reduced ${ }^{18}$ as is expression of Fc $\gamma$ RII $(\mathrm{CD} 32)^{19}$ and the ability to process native soluble antigens. ${ }^{16}$ Concomitantly, certain intracellular changes occur including loss of acidic organelles associated with the ability to process exogenous antigen, ${ }^{22}$ and reduced synthesis of invariant chain ${ }^{23}$ which is involved in the correct assembly of MHC class II molecules. However, surface expression of MHC class II is increased and expression of IL-2R $\alpha$ chain (CD25) is acquired. ${ }^{19}$ These changes are associated with the development of potent immunostimulatory function and increased expression of B7-1 and B7-2.21 Many of these changes appear to be dependent upon the influence of cytokines and, in particular, upon GM-CSF. It is known, for instance, that LC viability and acquisition of immunostimulatory capacity is dependent upon the presence of GM-CSF in culture ${ }^{24}$ and that IL-1 may synergise in the acquisition of stimulatory capacity. ${ }^{25}$ TNF- $\alpha$ on the other hand appears to maintain LC viability without promoting the development of immunostimulatory capacity. ${ }^{26} \mathrm{GM}-\mathrm{CSF}$ is also known to up-regulate expression of B7 molecules on murine LC and kidney interstitial DC. ${ }^{21}$ The LC in intact skin in tissue culture undergo similar changes, ${ }^{21,} 27$ presumably under the influence of cytokines produced in situ by keratinocytes and it is assumed that the same 'maturation' process occurs in vivo, although there is little direct evidence for this.

In summary, there is now persuasive evidence that non-lymphoid DC are 'immature' lymphoid DC. This is strongest for LC but the same appears to be true of other non-lymphoid DC. The 'maturation' process is dependent upon GM-CSF and other cytokines in vitro but it is uncertain whether a similar cytokine dependence operates in vivo (Fig. 1).

\section{MIGRATORY DENDRITIC CELLS}

Early studies of the afferent lymph draining a variety of tissues identified a population of 'veiled macrophages' comprising about $20 \%$ of the afferent lymph leucocytes ${ }^{28}$ which have subsequently been shown to resemble LC and other DC. . $^{29-31}$ They are now known as veiled cells (VC) and appear to be lymphborne DC involved in the transport of antigen to the draining lymph nodes ${ }^{32,33}$ where they probably become short-lived IDC. ${ }^{34}$ Having reached the lymph node there is no evidence that $\mathrm{VC}$ leave via the blood and they are rarely found in the efferent lymph or normal thoracic duct lymph. Thus, it appears that they do not recirculate.

A migratory route for non-lymphoid DC via the blood has also been defined. This was demonstrated following experimental transplantation of fully vascularised tissues in which donor strain leucocytes $^{35,36}$ with the characteristics of $\mathrm{DC}^{2}$ were identified within the white pulp of the recipient spleen 2-4 days after transplantation.

The factors that regulate the migration of DC are poorly understood. As discussed above, VC are found in afferent lymph draining normal tissues but the number of cells can be dramatically increased by the induction of local inflammation through application of contact sensitising agents. ${ }^{37}$ This may be in response to local production of inflammatory mediators. Following skin transplantation, or skin organ culture, LC migrate from the epidermis to dermis and then apparently leave the skin via dermal lymphatics, ${ }^{27}$ and in this model it is clear that the stimulus to migration must originate within the skin. 


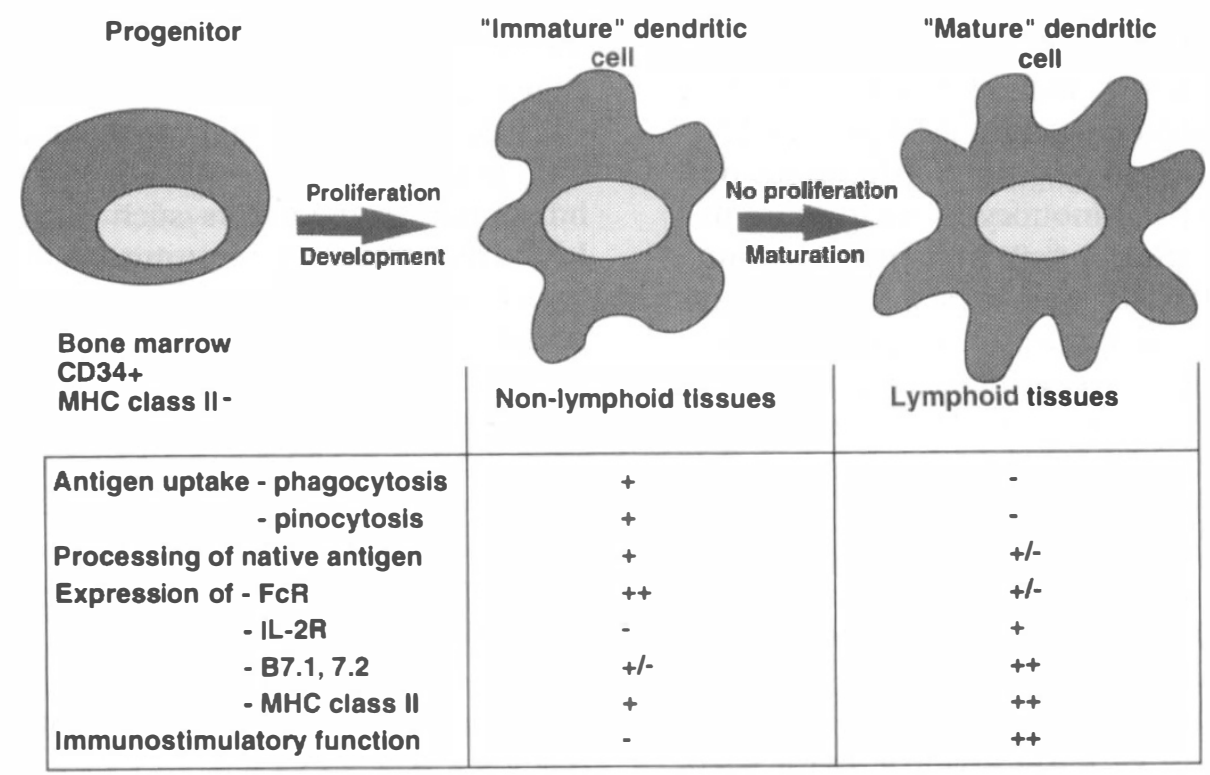

Fig. 1. Stages of dendritic cell development and 'maturation'. In tissue culture dendritic cells undergo a cytokine-dependent 'maturation' process.during which they become potent immunostimulatory cells.

It is known that keratinocytes can produce a variety of inflammatory mediators and cytokines and they could, therefore, be one source of mediators of LC migration.

There is accumulating evidence that certain cytokines may promote migration of non-lymphoid DC. Systemic administration of lipopolysaccharide (LPS), which is known to induce the release of a variety of cytokines (including TNF- $\alpha$, IL-1, IL-6, IL8 and interferons) increased the release of $\mathrm{VC}$ into pseudoafferent lymph in rats, ${ }^{30,38}$ and in mice it appears to induce migration of epidermal LC and interstitial DC of the heart, kidneys and liver. ${ }^{39}$ Qualitatively similar responses were observed following systemic administration of TNF- $\alpha$ or IL-1 but not IL- $2^{39}$ and, in other studies, following administration of IFN- $\alpha$ or IFN- $\beta .^{40}$ Systemic, or local, injection of IL-1 $\beta$ has been reported to induce migration of $\mathrm{LC}^{41}$ and intracutaneous injection of TNF- $\alpha$ is reported to increase the number of DC in the draining lymph nodes ${ }^{42}$ - indirect evidence that TNF- $\alpha$ stimulated LC migration.

Studies on migration of corneal LC have provided further insight into which agents may be chemoattractant for DC. Surgical incision, or insertion of $1 \mu \mathrm{m}$ latex beads into the central cornea, appears to stimulate centripetal migration of limbic LC, possibly as a consequence of the actions of local inflammatory mediators that may be produced by the corneal epithelium. ${ }^{43}$ This is supported by the observation that centripetal migration was induced by direct injection of the cornea with IL-1, which is known to be produced by corneal epithelium following exposure to latex beads. ${ }^{44}$

\section{BONE MARROW PROGENITORS AND DC PRECURSORS IN THE BLOOD}

In the past the study of DC has been frustrated by consistent failure to identify DC progenitors with the capacity to proliferate in vitro. This necessitated laborious procedures for isolation of small numbers of DC from lymphoid and non-lymphoid tissues before meaningful functional studies could be undertaken. Several early papers demonstrated the feasibility of obtaining DC precursors from bone marrow $^{45,46}$ but only in small numbers, but in 1992 Inaba et al. succeeded in culturing cells with the characteristics of fully differentiated DC in large numbers from mouse blood ${ }^{47}$ and bone marrow. ${ }^{48}$ This process was absolutely dependent upon GMCSF, under the influence of which DC apparently arose from pluripotent, MHC class $\mathrm{II}^{-}$, common myeloid progenitors that had the capacity to generate granulocytes, monocytes or DC, depending upon the culture conditions. ${ }^{49}$ In culture, small aggregates of proliferating MHC class $\mathrm{II}^{-}$cells, with phagocytic capacity, ${ }^{50}$ eventually gave rise to typical non-proliferating, MHC class $\mathrm{II}^{+}$, highly motile DC that had the capacity to initiate primary $\mathrm{T}$ cell responses in vitro and to home to $\mathrm{T}$ dependent areas in the draining popliteal lymph nodes when they were injected into the footpads of mice in vivo. ${ }^{47}$

Similar cytokine-derived 'DC' have now been cultured from human bone marrow ${ }^{51}$ and both neonatal ${ }^{52}$ and adult blood. ${ }^{53}$ These cells are somewhat less well characterised than in the mouse, in part because of lack of lineage-specific markers but also because of lack of studies on their capacity to home to the lymphoid tissues. Thus, although they are widely accepted as bona fide DC, there is still some uncertainty as to their true identity. 'DC' were 
generated from the CD34+* MHC class $\mathrm{II}^{-}$stem cells of human bone marrow and neonatal cord blood under the combined influence of GM-CSF and TNF$\alpha .{ }^{51,52}$ Culture in GM-CSF alone produced only granulocytes and typical monocytes, suggesting that DC arose from a pluripotent myeloid progenitor which, as in the mouse, was present in the bone marrow and blood. In contrast, culture of human 'DC' from adult blood was most efficient in the presence of GM-CSF and IL-4. ${ }^{53,54}$ These cells exhibited a relatively immature phenotype in that they had abundant micropinocytic activity, and efficient antigen processing capacity, low expression of MHC class II and co-stimulatory molecules (B7 and ICAM-1), and little capacity to activate T cells. ${ }^{54}$ However, when cultured in TNF- $\alpha$ or LPS they apparently underwent a maturation process and developed into cells with the typical features of lymphoid DC. ${ }^{54}$ These changes were analogous to those undergone by LC and other non-lymphoid DC during culture (Fig. 1).

DC precursors in the blood are en route from the bone marrow to seed tissues with 'immature' DC (non-lymphoid DC) but it is unknown whether normal tissues contain a significant pool of marrowderived MHC class $\mathrm{II}^{-}$precursors that retain proliferative potential. It is known that classic MHC class $\mathrm{II}^{+} \mathrm{LC}$ and DC isolated from spleen or lymph nodes do not proliferate in culture, but the identification of pluripotent progenitors in the blood indicates that divergence of the monocytic and DC lineages is incomplete at this stage of development and suggests that peripheral tissues might contain DC precursors with the capacity to proliferate. There is direct evidence for this in the thymus of the mouse $^{55}$ and possibly other tissues ${ }^{56}$ but in the human this is largely speculative.

It has been suggested that certain transplanted organs may contain DC progenitors, but the evidence for this is not yet secure. Clinical transplantation of organs such as the liver and small bowel under conventional immunosuppression is reported to be associated with seeding of the recipient tissues by cells, probably leucocytes, that have dendritic morphology and express high levels of donor MHC class II. ${ }^{57,58}$ They may persist in the recipient for many years and it has been suggested that they may be donor DC responsible for the induction and maintenance of operational tolerance to the transplanted organ. ${ }^{58,59}$ However, there is no conclusive evidence that they are DC or that they are actively involved in induction or maintenance of tolerance, ${ }^{60}$ but their existence does suggest that the transplanted organs contained leucocyte stem cells which seeded

*CD34 is a polypeptide of unknown function which is expressed on the surface of haemopoietic stem cells and possibly endothelium. the recipient tissues via the blood. Clearly, further characterisation of these cells is required.

Little is known about how seeding of the tissues by DC precursors is regulated but it appears that inflammatory mediators such as those induced by LPS can stimulate recruitment of MHC class $\mathrm{II}^{-}$ leucocytes into murine tissues which have the potential to develop into cells with many of the characteristics of DC. ${ }^{61}$ Biologically this makes sense since, as noted above, local inflammation, or administration of inflammatory mediators, depletes tissues of MHC class $\mathrm{II}^{+}$DC which (presumably) must be replaced by precursors recruited from the bone marrow, or by proliferation of precursors resident within the tissues.

\section{CONCLUSION}

DC are a diverse lineage of leucocytes that is widely disseminated throughout the body. They arise from MHC class $\mathrm{II}^{-}$common myeloid progenitors in the bone marrow and, broadly speaking, they exist in the tissues in two stages of maturation. Those in the nonlymphoid tissues are immature cells that act as sentinels specialised for antigen capture and processing. Under the influence of inflammatory mediators they migrate via the lymph to draining lymph nodes, or via the blood to the spleen, where as mature

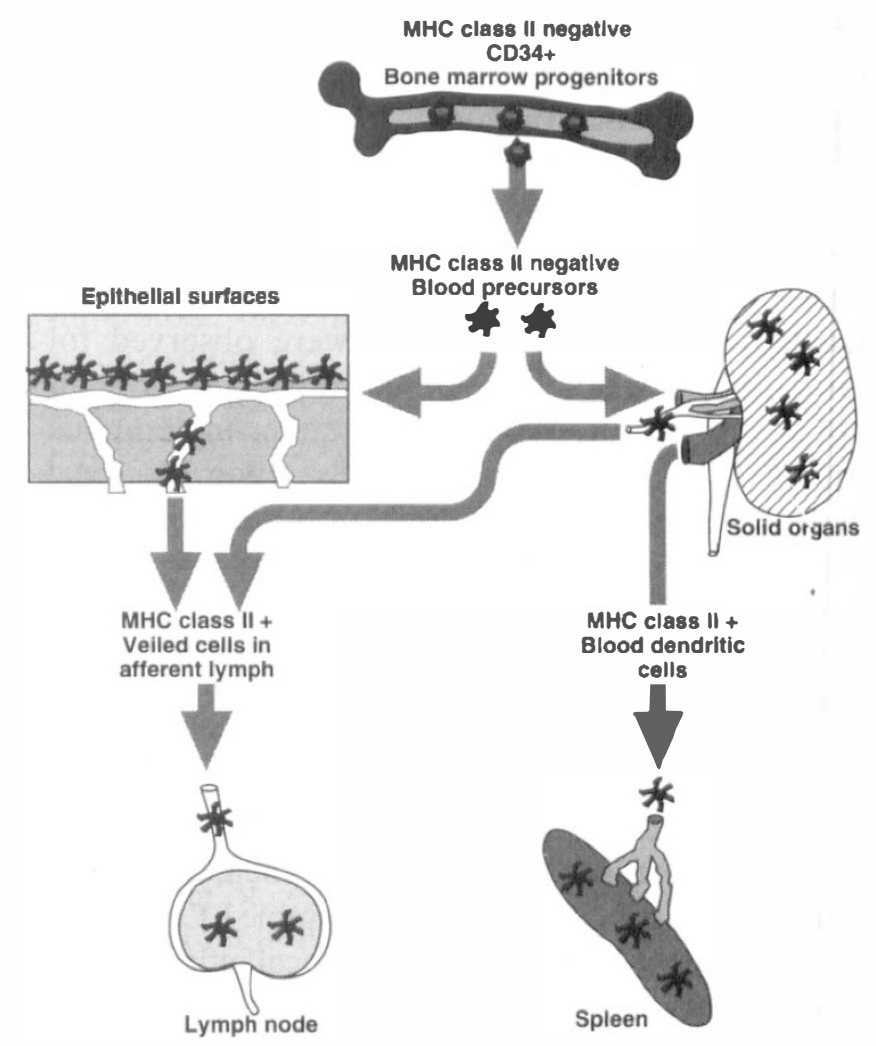

Fig. 2. Migration pathways for dendritic cells (DC). DC develop from progenitors in the bone marrow and migrate via the blood to seed the tissues. DC in the non-lymphoid tissues migrate via the blood or lymph and 'home' to the Tdependent areas of the lymph nodes or spleen. 
immunostimulatory DC, in the T-dependent areas, they trigger activation of antigen-specific $\mathrm{T}$ cells (Fig. 2).

Much remains to be discovered about the regulation of DC proliferation, development, migration and maturation, but a better understanding of these processes may suggest new ways in which the initiation of $\mathrm{T}$ and $\mathrm{T}$-dependent immune responses may be manipulated for clinical gain.

Key words: Dendritic cell, Differentiation, Immunostimulation, Maturation, Migration, Phagocytosis, Phenotype, Progenitors.

\section{REFERENCES}

1. Steinman RM. The dendritic cell system and its role in immunogenicity. Annu Rev Immunol 1991;9:271-96.

2. Roake JA. Dendritic cells and the initiation of the immune response to organ transplants. Transplant Rev 1994;8:37-52.

3. Hart DNJ, Fabre JW. Demonstration and characterisation of Ia-positive dendritic cells in the interstitial connective tissue of rat heart and other tissues, but not brain. J Exp Med 1981;153:347-61.

4. Romani N, Schuler G. The immunologic properties of epidermal Langerhans cells as a part of the dendritic cell system. Springer Semin Immunopathol 1992; 13:265-79.

5. Holt PG, McMenamin C, Schon-Hegrad MA. Studies on the surface phenotype and functions of dendritic cells in parenchymal lung tissue of the rat. Immunology 1992;75:582-7.

6. Austyn JM, Hankins DF, Larsen CP, Morris PJ, Rao AS, Roake JA. Isolation and characterisation of dendritic cells from mouse heart and kidney. J Immunol 1994;152:2401-10.

7. Klinkert WEF, LaBadie JH, Bowers WE. Accessory and stimulating properties of dendritic cells and macrophages isolated from various rat tissues. J Exp Med 1982;156:1-19.

8. Steinman RM, Cohn ZA. Identification of a novel cell type in peripheral lymphoid organs of mice. I. Morphology, quantitation, tissue distribution. J Exp Med 1973;137:1142-62.

9. Fairchild PF, Austyn JM. Thymic dendritic cells: phenotype and function. Int Rev Immunol 1990;6:187-96.

10. Steinman RM, Cohn ZA. Identification of a novel cell type in peripheral lymphoid organs of mice. II. Functional properties in vitro. J Exp Med 1974; 139:380-97.

11. Steinman RM, Dinah SL, Cohn ZA. Identification of a novel cell type in peripheral lymphoid organs of mice. III. Functional properties in vivo $\mathrm{J}$ Exp Med 1974;139:1431-45.

12. Steinman RM, Adams JC, Cohn ZA. Identification of a novel cell type in peripheral lymphoid organs of mice. IV. Identification and distribution in mouse spleen. $\mathbf{J}$ Exp Med 1975;141:804-20.

13. Austyn JM, Kupiec-Weglinski JW, Hankins DF, Morris PJ. Migration patterns of dendritic cells in the mouse: homing to $\mathrm{T}$ cell-dependent areas of spleen, and binding with marginal bone. $J$ Exp Med 1988;167:646-51.

14. Kupiec-Weglinski JW, Austyn JM, Morris PJ. Migration patterns of dendritic cells in the mouse: traffic from blood, and $\mathrm{T}$ cell-dependent and -independent entry to lymphoid tissues. J Exp Med 1988;167:632-45.
15. Shelly WB, Juhlin L. Langerhans cells form a reticuloepithelial trap for external contact antigens. Nature 1976;261:46-7.

16. Romani N, Koide S, Crowley M, Witmer-Pack M, Livingstone AM, Fathman CG, et al. Presentation of exogenous protein antigens by dendritic cells to $T$ cell clones: intact protein is presented best by immature, epidermal Langerhans cells. J Exp Med 1989; 169:1169-78.

17. Schuler G, Steinman RM. Murine epidermal Langerhans cells mature into potent immunostimulatory dendritic cells in vitro. J Exp Med 1985;161:526-46.

18. Reis e Sousa C, Stahl PD, Austyn JM. Phagocytosis of antigens by Langerhans cells in vitro. J Exp Med 1993;178:509-19.

19. Romani N, Lenz A, Glassel H, Stössel H, Stanzl U, Majdic $\mathrm{O}$, et al. Cultured human Langerhans cells resemble lymphoid dendritic cells in phenotype and function. J Invest Dermatol 1989;93:600-9.

20. Larsen CP, Ritchie SC, Pearson TC, Lowry RP. Functional expression of the costimulatory molecule, B7/BB1, on murine dendritic cell populations. J Exp Med 1992;176:1215-20.

21. Larsen CP, Ritchie SC, Hendrix R, Linsley PS, Hathcock KS, Hodes RJ, et al. Regulation of immunostimulatory function and costimulatory molecule (B7-1 and B7-2) expression on murine dendritic cells. J Immunol 1994;152:5208-19.

22. Stössel H, Koch F, Kämpgen E, Stöger P, Lenz A, Heufler $\mathrm{C}$, et al. Disappearance of certain acidic organelles (endosomes and Langerhans cell granules) accompanies loss of antigen processing capacity upon culture of epidermal Langerhans cells. J Exp Med 1990;172:1471-82.

23. Puré E, Inaba K, Crowley MT, Tardelli L, Witmer-Pack MD, Ruberti G, et al. Antigen processing by epidermal Langerhans cells correlates with the level of biosynthesis of major histocompatibility complex class II molecules and expression of invariant chain. J Exp Med 1990;172:1459-69.

24. Witmer-Pack MD, Oliver W, Valinsky J, Schuler G, Steinman RM. Granulocyte/macrophage colony-stimulating factor is essential for the viability and function of cultured murine epidermal Langerhans cells. J Exp Med 1987;166:1484-98.

25. Heufler C, Koch F, Schuler G. Granulocyte/macrophage colony-stimulating factor and interleukin-1 mediate the maturation of murine epidermal Langerhans cells into potent immunostimulatory dendritic cells. J Exp Med 1988;167:700-5.

26. Koch F, Heufler C, Kämpgen E, Schneeweiss D, Böck $\mathrm{G}$, Schuler G. Tumour necrosis factor $\alpha$ maintains the viability of murine epidermal Langerhans cells in culture, but in contrast to granulocyte/macrophage colony-stimulating factor, without inducing their functional maturation. J Exp Med 1990;171:159-71.

27. Larsen CP, Steinman RM, Witmer-Pack M, Hankins DF, Morris PJ, Austyn JM. Migration and maturation of Langerhans cells in skin transplants and explants. $\mathbf{J}$ Exp Med 1990;172:1483-93.

28. Smith JB, McIntosh GH, Morris B. The traffic of cells through tissues: a study of peripheral lymph in sheep. $J$ Anat 1970;107:87-100.

29. Bujdoso R, Hopkins J, Dutia BM, Young P, McConnell I. Characterisation of sheep afferent lymph dendritic cells and their role in antigen carriage. J Exp Med 1989;170:1285-302.

30. MacPherson GG. Properties of lymph-borne (veiled) dendritic cells in culture. I. Modulation of phenotype, 
survival and function: partial dependence on GM-CSF. Immunology 1989;68:102-7.

31. MacPherson GG, Fossum S, Harrison B. Properties of lymph-borne (veiled) dendritic cells in culture II. Expression of the IL-2 receptor: role of GM-CSF. Immunology 1989;68:108-13.

32. Kripke ML, Munn CG, Jeevan A, Tang J-M, Bucana C. Evidence that cutaneous antigen-presenting cells migrate to regional lymph nodes during contact sensitisation. J Immunol 1990;145:2833-8.

33. Moll H, Fuchs H, Blank C, Röllinghoff $M$. Langerhans cells transport of Leishmania major from the infected skin to the draining lymph node for presentation to antigen-specific $\mathrm{T}$ cells. Eur $\mathrm{J}$ Immunol 1993; 23:1595-601.

34. Fossum S. Lymph-borne dendritic leucocytes do not recirculate, but enter the lymph node paracortex to become interdigitating cells. Scand $J$ Immunol 1988;27:97-105.

35. Larsen CP, Morris PJ, Austyn JM. Migration of dendritic leucocytes from cardiac allografts into host spleens: a novel pathway for initiation of rejection. $\mathrm{J}$ Exp Med 1990;171:307-14.

36. Codner MA, Shuster BA, Steinman RM, Harper AD, La Trenta GS, Hoffman LA. Migration of donor leucocytes from limb allografts into host lymphoid tissues. Ann Plastic Surg 1990;25:353-9.

37. Drexhage HA, Mullink H, de Groot J, Clarke J, Balfour BM. A study of cells present in peripheral lymph of pigs with special reference to a type of cell resembling the Langerhans cell. Cell Tissue Res 1979;202:407-30.

38. MacPherson GG, Jenkins CD, Stein MJ, Edwards C. Endotoxin-mediated dendritic cell release from the intestine: characterisation of released dendritic cells and TNF dependence. J Immunol 1995;159:1317-25.

39. Roake JA, Rao AS, Morris PJ, Hankins DF, Larsen CP, Austyn JM. Dendritic cell loss from non-lymphoid tissues following systemic administration of lipopolysaccharide, tumour necrosis factor, and interleukin-1. J Exp Med 1995 (in press).

40. Maguire JE, Gresser I, Williams AH, Kielpinski GL, Colvin RB. Modulation of expression of MHC antigens in the kidneys of mice by murine interferon $-\alpha / \beta$. Transplantation 1990;49:130-4.

41. Lundqvist EN, Bäck O. Interleukin-1 decreases the number of $\mathrm{Ia}+$ epidermal dendritic cells but increases their expression of Ia antigen. Acta Derm Venereol (Stockh) 1990;70:391-4.

42. Cumberbatch M, Kimber I. Dermal tumour necrosis factor- $\alpha$ induces dendritic cell migration to draining lymph nodes and possibly provides one stimulus for Langerhans cell migration. Immunology 1992;75:257.

43. Niederkorn JY. Immune privilege and immune regulation in the eye. Adv Immunol 1990;48:191-226.

44. Niederkorn JY, Peeler JS, Mellon J. Phagocytosis of particulate antigens by corneal epithelial cells stimulates interleukin-1 secretion and migration of Langerhans cells into the central cornea. Reg Immunol 1989;2:183-90.

45. Bowers WE, Berkowitz MR. Differentiation of dendritic cells in cultures of rat bone marrow cells. J Exp Med 1986;163:872-83.

46. Reid CDL, Fryer PR, Clifford C, Kirk A, Tikerpae J, Knight SC. Identification of hematopoietic progenitors of macrophages and dendritic Langerhans cells ( DL$\mathrm{CFU}$ ) in human bone marrow and peripheral blood. Blood 1990;76:1139-49.

47. Inaba K, Steinman RM, Witmer-Pack MD, Aya H,
Inaba $\mathrm{M}$, Sudo $\mathrm{T}$, et al. Identification of proliferating dendritic cell precursors in mouse blood. J Exp Med 1992;175:1157-67.

48. Inaba $\mathrm{K}$, Inaba $\mathrm{M}$, Romani $\mathrm{N}$, Aya $\mathrm{H}$, Deguchi $\mathrm{M}$, Ikehara $\mathrm{S}$, et al. Generation of large numbers of dendritic cells from mouse bone marrow cultures supplemented with granulocyte/macrophage colonystimulating factor. J Exp Med 1992;176:1693-702.

49. Inaba K, Inaba M, Deguchi M, Hagi K, Yasumizu R, Ikehara S, et al. Granulocytes, macrophages, and dendritic cells arise from a common major histocompatibility complex class II-negative progenitor in mouse bone marrow. Proc Natl Acad Sci USA 1993;90:3038-42.

50. Inaba $\mathrm{K}$, Inaba $\mathrm{M}$, Naito $\mathrm{M}$, Steinman RM. Dendritic cell progenitors phagocytose particulates, including Bacillus Calmette-Guerin organisms, and sensitise mice to mycobacterial antigens in vivo. J Exp Med 1993;178:479-88.

51. Caux C, Dezutter-Dambuyant C, Schmitt D, Banchereau J. GM-CSF and TNF- $\alpha$ cooperate in the generation of dendritic Langerhans cells. Nature 1992;360:258-61.

52. Reid CDL, Stackpoole A, Meager A, Tikerpae J. Interactions of tumor necrosis factor with granulocytemacrophage colony-stimulating factor and other cytokines in the regulation of dendritic cell growth in vitro from early bipotent CD34+ progenitors in human bone marrow. J Immunol 1992;149:2681-8.

53. Romani N, Gruner S, Brang D, Kämpgen E, Lenz A Trockenbacher $\mathrm{B}$, et al. Proliferating dendritic cell progenitors in human blood. J Exp Med 1994; 180:83-93.

54. Sallusto F, Lanzavecchia A. Efficient presentation of soluble antigen by cultured human dendritic cells is maintained by granulocyte/macrophage colony-stimulating factor plus interleukin 4 and downregulated by tumour necrosis factor $\alpha$. J Exp Med 1994;179:1109-18.

55. Inaba $\mathrm{K}$, Witmer-Pack MD, Inaba $M$, Muramatsu $S$, Steinman RM. The function of $\mathrm{Ia}^{+}$dendritic cell and $\mathrm{Ia}^{-}$dendritic cell precursors in thymocyte mitogenesis to lectin and lectin plus interleukin 1. J Exp Med 1988;167:149-62.

56. Lu L, Woo J, Rao AS, Li Y, Watkins SC, Qian S, et al. Propagation of dendritic cell progenitors from normal mouse liver using granulocyte/macrophage colonystimulating factor and their maturational development in the presence of type-1 collagen. J Exp Med 1994;179:1823-34.

57. Starzl TE, Demetris AJ, Murase N, Ildstad S, Ricordi C, Trucco M. Cell migration, chimerism, and graft acceptance. Lancet 1992;339:1579-82.

58. Starzl TE, Demetris AJ, Trucco M, Murase N, Ricordi $\mathrm{C}$, Ildstad S, et al. Cell migration and chimerism after whole organ transplantation: the basis of graft acceptance. Hepatology 1993;17:1127-52.

59. Starzl TE, Demetris AJ, Trucco M, Zeevi A, Ramos H, Terasaki $\mathrm{P}$, et al. Chimerism and donor-specific nonreactivity 27 to 29 years after kidney allotransplantation. Transplantation 1993;55:1272-7.

60. Steinman RM, Inaba K, Austyn JM. Donor-derived chimerism in recipients of organ transplants [Editorial]. Hepatology 1993;17:1153-6.

61. Roake JA, Rao AS, Morris PJ, Hankins DF, Larsen CP, Austyn JM. Systemic lipopolysaccharide recruits dendritic cell progenitors to non-lymphoid tissues. Transplantation 1995 (in press). 